\title{
Swiss and Turkish Pre-service Science Teachers' Anxiety Levels for Educational Technology
}

\author{
Hulya Aslan Efe ${ }^{1}$, Rifat Efe ${ }^{2}$ \\ ${ }^{1}$ Dicle University, Ziya Gokalp Education Faculty, Department of Primary Science Education, Diyarbakır, Turkey \\ ${ }^{2}$ Dicle University, Ziya Gokalp Education Faculty, Department of Biology Education, Diyarbakır, Turkey \\ Correspondence: Hulya Aslan Efe, Dicle University, Ziya Gokalp Education Faculty, Department of Primary Science \\ Education, 21280, Diyarbakır, Turkey.
}

Received: March 25, 2016 Accepted: April 13, $2016 \quad$ Online Published: April 20, 2016

doi:10.11114/jets.v4i7.1492 URL: http://dx.doi.org/10.11114/jets.v4i7.1492

\begin{abstract}
This study aims to culturally explain pre-service science teachers' instructional technology-related anxiety levels by analyzing the variables of their instructional technology using experiences, frequency of using instructional technologies, access to instructional technologies, instructional technology-related attitude and their instructional technology-related self-efficacy perceptions. The participants were 538 pre-service teachers studying at the Dicle University Ziya Gokalp Education Faculty and 188 pre-service teachers studying at the University of Teacher Education during the 2011-2012 academic year. The findings indicate that the higher the degree of Turkish and Swiss pre-service science teachers' technology experience, the higher instructional technology-related anxiety levels they have. Furthermore, the frequency of Turkish pre-service science teachers' technology use is in reverse ratio to their instructional technology-related anxiety level. However, the frequency of Swiss pre-service science teachers' technology use was found to be in direct ratio to their instructional technology-related anxiety levels.
\end{abstract}

Keywords: cross-cultural comparison, anxiety, educational technology

\section{Introduction}

In Turkey, as in the rest of the world, education systems are affected by the technological developments. Technology is an area that comprises various social and economic activities and organizations that require the application of technical knowledge to life practices. Technology can be described as the application of scientific principles and innovations to solve problems in order to make life easier. At the same time, it changes the relationships among subject fields and disciplines and leads to an exponential growth of knowledge (Middlehurst, 1999; Williams \& Kingham, 2003). Societies aim to equip individuals with this increasing knowledge through high-quality education systems by utilizing technology (MEB, 2004). As such, in today's world, education and the use of technology in education have become two inseparable concepts (McCannon \& Crews, 2000; Komis, Ergazakia \& Zogzaa, 2007) because technology is the key for accessing, using, producing, and sharing knowledge (Halis, 2002). With this increasing awareness, technology offers innovative ways to learners to facilitate their learning (Sarıtaş \& Üner, 2013). From a constructivist perspective, many researchers agree that learners gain personal knowledge, have opportunities for rich learning experiences and change these experiences through instructional technologies (Buzzard, Crittenden, Crittenden, \& McCarty, 2011, Garris, Ahlers $\&$ Driskell, 2002). The research findings obtained over the past 20 years offer some evidence that instructional technologies used in classroom environments have a positive contribution to learning (Mumtaz, 2000). Despite positive contributions made by instructional technologies to the classroom environment, the actual use of advanced technology products as teaching tools in the classroom environment is surprisingly rare (Ertmer, 2005). In spite of all the positive research findings, the technology investments at schools and technology-based education programs, adoption of such instructional technologies at schools by teachers is progressing at a disappointingly slow rate (Yıldırım, Koçak \& Kirazcı 2001; Seferoğlu, Akbıyık \& Bulut, 2008). According to Ertmer (2005), many teachers still use computers for low-level tasks such as searching for information on the Internet, or word-ordering. The studies in Turkey support this conclusion as well. For instance, Demiraslan and Koçak-Usluel (2005) found that, while most teachers can use a computer, they do not conduct any activities to integrate the IT technologies into the process of teaching and learning. Findings from many studies demonstrate that a majority of teachers use computer only for low-level tasks like "Word 
processor", "www", "e-mail" and few use it for instruction purposes such as "Calculation Tables", "Education Software CDs", and "databases" (Akkoyunlu, 2002; Aşkar \& Koçak-Usluel, 2003; Demiraslan \& Koçak-Usluel, 2005). Technology-enhanced classrooms require teachers who are actively able to use technology. However, the number of teachers who can integrate instructional technologies into their classroom teaching is quite low (Kozma, 2003). This is because by its nature, technology can be intimidating, confusing and disappointing for both teachers and students (King, 2002), and thus there are some factors preventing classroom utilization of instructional technologies by teachers while they acknowledge its benefits (Beak, Jung \& Kim, 2008). According to Pelgrum (2001), teachers' failure at using instructional technologies may be caused by their inadequate cognitive, affective and psychomotor skills. Also, in the case of inability to use technology or feeling incompetent about using it turns it into a nuisance rather than a facilitator, which underscores the importance of teachers' instructional technology-related anxiety level. An individual's prejudices against or fears of using instructional technology or thinking about the results of using instructional technology are called technology anxiety (Marcoulides, 1989). Technology Anxiety is related to users' fears or fearful experiences they have acquired during the technology courses they have attended or such fears that arise when they think about using technology (Chua, Chen \& Wong, 1999). Differing from other negative stimuli, technology anxiety involves some potential negative emotional fears and reactions like appearing stupid or feeling the urge to vandalize instructional technologies (Kanfer \& Heggestad, 1997). Technology anxiety also has a negative impact on individuals' technology use and technology-related task performances (Doyle, Stamouli \& Huggard, 2005). As such, it was reported in the relevant literature that technology anxiety negatively affects individuals' technology use and that teachers with technology anxiety hesitate to integrate technology into their educational environments (Ceyhan, 2006). It is known that one of the factors affecting instructional technology-related anxiety level is instructional technology-related attitude (Mc Ilroy, Bunting, Tierney, \& Gordon, 2001, Coffin \& Mackintyre 2000). Instructional technology-related negative and positive attitudes play a determinant role in anxiety (Blignaut, Mc Donald \& Tolmie, 2002). Jawahar and Elango (2001) found that a high computer anxiety led to negative attitudes toward computers. Positive experiences in technology use, on the other hand, leads to highly positive attitudes towards technology (Chau, 2001; Zhao, Tan \& Mishra, 2001; Huang \& Liaw, 2005; Khine, 2001; Kumar \& Kumar, 2003). Attitude toward technology is defined by Smith, Caputi and Rawstorne (2000) as an individual's general assessment of technology or their feeling of sympathy or antipathy for technology. In order for the technology use at schools to reach the desired level, and for it to be used effectively, first and foremost the attitudes of teachers and students toward technology need to be known. Attitude toward technology is one of the most crucial factors determining the use of technology (Altun, 2002). Another factor that plays a role in technology-related anxiety level is perception of technological self-efficacy. Technology-related anxiety and perception of technological self-efficacy are highly related and interactive concepts (Kutluca \& Ekici, 2010). Technological self-efficacy is an individual's judgment about his/her own skills in using technology in various areas (Compeau \& Higgins, 1995). Studies on the perception of technological self-efficacy show that individuals with high level of technological self-efficacy perception are more motivated to get involved in technological activities and they enjoy such activities (Seferoğlu, 2005). The individuals with high technological self-efficacy are found to more easily overcome any problem that they encounter while using technology (Usluel \& Seferoğlu, 2003). As such, the individuals with high degree of technology self-efficacy belief were found to be more eager to participate in activities involving the use of technology, to have a higher expectation from such work, and to more easily cope with the technological problems they come across (Salanova, Grau, Cifre \& Llorens, 2000; Hasan, 2003).

\subsection{Cross-cultural Perspective}

It is notable that intercultural studies usually compare eastern and western cultures. Such studies state that in the collectivist eastern countries like Turkey, groups rather than individuals are more important and humbleness instead of pride is adopted. Western countries like Switzerland are described as individualist. In individualist cultures, values of an individual are of higher importance than group values, and pride comes before humbleness (Bond, 1986; Wang \& Leichtman, 2000). This cultural difference has an impact on many studies conducted in social sciences. Rosen and Weil (1995) stress that related to its own culture, each country has a unique computer anxiety model. Harris, Kemmerling and North (2002) found that participants displayed significant differences between computer anxiety levels and personal computer use by cultural variable. Blignaut, Mc Donald and Tolmie (2002) studied university students' computer-related task attitudes, computer anxieties and visual spatial skills. Their findings revealed the African and European students had similar attitudes toward computer use. The students' attitudes indicated a positive change after their computer using experiences. Computer-related anxieties of African students who had taken computer training were significantly higher than those of the European students.

\subsection{The Present Study}

Given the increasing importance of using instructional technologies in education, as the future teachers to provide instructional technologies in their classrooms and to create the appropriate environment and opportunities for their 
students, pre-service science teachers' anxiety about using instructional technologies is becoming more and more important. While in the classroom use of instructional technologies in almost all the subjects is viewed as important and its more extensive application is encouraged, there is a higher number of studies conducted on the use of instructional technologies in science subjects due to the better suitability of their course contents for such instruction. The intercultural research focuses mostly on anxiety, attitude and self-efficacy regarding the computer as an instructional technology Marcoulides \& Wang, 1990; Brosnan \& Lee, 1998; Durnell, Haag \& Laithwaite, 2000; Tekinaslan, 2008). In their study carried out with 2456 university students from 10 countries, Rosen and Weil (1995) found cultural difference to have an impact on computer anxiety. Furthermore, their findings indicate that there are many technophobic students in many different countries. Ursavaş, McIlroy and Şahin (2011) studied Turkish and British university students' computer anxiety level and concluded that computer-related anxiety level differs culturally. These studies demonstrate that the concept of anxiety has a unique model for each culture and technology anxiety has a substantial negative effect on technology use. Thus, it is important to determine the factors that affect pre-service science teachers' instructional technology-related anxiety status. Hence, the aim of the present study is to culturally explain the instructional technology-related anxiety based on the variables of technology experience, frequency of technology use, availability of access, perceived instructional technology-related self-efficacy, and instructional technology-related attitude.

\section{Methodology of Research}

\subsection{Participants}

Participants from Turkey included 538 (M: 181, F: 357) pre-service science teachers in a science teacher education course at Dicle University, Ziya Gokalp Education Faculty in the 2011-2012 academic year.

The Swiss participants included 188 (M: 37, F: 151) pre-service science teachers in teacher education at St. Gallen Teacher Education University in the 2011-2012 academic year.

\subsection{Data Collection Methods}

Pre-service science teachers' anxiety towards educational technology was measured through the "State Anxiety Scale" developed by Spielberger (1983). The scale consists of 20-Likert type items. The Kaiser-Meyer-Olkin (KMO) value was .917, and the Bartlett's Test of Sphericity value was 4,635 (DF: 190, $\mathrm{p}<0.000$ ). The single factor accounted for $42,664 \%$ of the variance. The reliability of the questionnaire was measured through Cronbach's alpha, which was .930 for the entire scale.

The data for pre-service science teachers' self-efficacy regarding educational technology were collected through the "Self-Efficacy Perception for Technology Scale", which included 18 Likert-type items developed by Aşkar and Umay (2001). The factor analysis of the scale demonstrated that the KMO value was .791, and the Bartlett's Test of Sphericity value was 8,091 (DF: 153, p <0.000). The reliability of the questionnaire was measured through Cronbach's alpha, which was .710 for the entire scale.

The data for attitudes were collected using the "Pre-Service Science Teachers' Attitude towards Educational Technology Scale" developed by Efe (2011). The five-point Likert scale invited pre-service science teachers to respond to the items with "never", "very rare", "sometimes", "often", "always" or "none", "very little", "little", "high", or "very high", according to the nature of the item. The scale included four dimensions that consisted of 48 Likert-type items. The four dimensions on the scale were pre-service teachers' technology background, pre-service teachers' intention to use educational technology in their teaching, pre-service teachers' intention to provide opportunities for their students to use technology in the classroom, and the value of educational technology for learning science. The factor analysis of the scale for the present study revealed that the Kaiser-Meyer-Olkin (KMO) value was .895, and the Bartlett's Test of Sphericity value was 2,963 (DF: $3655, \mathrm{p}<0.000$ ).) The four factors of the scale accounted for $25.26 \%, 11.1 \%, 5.76 \%$, and $4.84 \%$ of the variance of the data, for a total of $46.96 \%$. The reliability of the questionnaire was measured through Cronbach's alpha, which was .915 for the entire scale. Cronbach's alphas were $.902, .863, .837$, and .874 for the first, second, third, and fourth variables, respectively.

\subsection{Data Analyze}

After the data collection, multiple linear regression analysis was used to find out to what degree the variables of technology experience, frequency of technology use, availability of access, instructional technology-related self-efficacy, and instructional technology-related attitude predict instructional technology-related anxiety. Before this analysis, the hypotheses of the multiple linear regression analysis were tested. The normality and linearity hypotheses of the multiple linear regression analysis were found to be satisfied. The tolerance, VIF and Durbin-Watson values were within acceptable range. 


\section{Findings}

The regression analysis results regarding how the variables of Turkish pre-service science teachers' technology experience, frequency of technology use, availability of access, instructional technology-related self-efficacy perception, instructional technology-related background, attitude toward having students use instructional technologies in the future, attitude toward using instructional technologies in classroom in the future, and contribution of instructional technologies to learning science predict instructional technology-related anxiety are presented in Table 1 .

Table 1. Multiple Regression Analysis Results Regarding the Prediction of Turkish Pre-service Science Teachers' Anxiety towards Educational Technology

\begin{tabular}{|c|c|c|c|c|c|c|c|c|}
\hline $\begin{array}{l}\text { Dependent } \\
\text { Variable }\end{array}$ & Predictors & $\mathrm{B}$ & $\begin{array}{l}\text { Std. } \\
\text { Error }\end{array}$ & $\beta$ & $\mathrm{t}$ & $\mathrm{p}$ & $\begin{array}{l}\text { Zero } \\
\text { order }\end{array}$ & Partial \\
\hline & Constant & 1.749 & .217 & & 8.052 & .000 & & \\
\hline & Technology experience & .152 & .030 & .229 & 5.036 & .000 & .396 & .214 \\
\hline Towards & Technology usage frequency & -.004 & .016 & -.012 & -.264 & .792 & -.274 & -.011 \\
\hline \multirow[t]{6}{*}{ Educational Technology } & $\begin{array}{l}\text { Availability of technology } \\
\text { access }\end{array}$ & -.049 & .027 & -.088 & -1.791 & .074 & -.342 & -.078 \\
\hline & $\begin{array}{ll}\text { Self-Efficacy } & \text { towards } \\
\text { educational technology } & \end{array}$ & -.037 & .040 & -.035 & -.921 & .357 & -.108 & -.040 \\
\hline & Technology background & .199 & .026 & .312 & 7.646 & .000 & .444 & .315 \\
\hline & $\begin{array}{l}\text { Attitudes to provide } \\
\text { opportunities for their students } \\
\text { to use technology in the } \\
\text { classroom }\end{array}$ & .058 & .028 & .107 & 2.057 & .040 & .184 & .089 \\
\hline & $\begin{array}{l}\text { Attitudes to use educational } \\
\text { technology in their teaching }\end{array}$ & .022 & .028 & .038 & .777 & .438 & .200 & .034 \\
\hline & $\begin{array}{l}\text { The value of educational } \\
\text { technology for learning science. } \\
R=.542 \quad R^{2}=.294 \\
F=27.478 \quad p=.000\end{array}$ & .007 & .031 & .009 & .211 & .833 & .012 & .009 \\
\hline
\end{tabular}

When the bivariate and partial correlations between the predictor variables and dependent variables were analyzed, a positive and average level $(r=.40)$ correlation was found between Turkish pre-service science teachers' instructional technology-related anxiety levels and their technology experience, but when the other variables were controlled, the correlation between these two variables was calculated as $r=.21$. However, there was a negative and low level $(r=-.27)$ correlation between the frequency of technology use and instructional technology-related anxiety. However, when the other variables were controlled, this correlation was determined to be $\mathrm{r}=-.01$. Similarly, a negative and low level $(\mathrm{r}=-.34)$ bivariate correlation was found between Turkish pre-service science teachers' technology access opportunity scores and their instructional technology-related anxiety levels. A low level negative correlation ( $\mathrm{r}=-.10)$ was found between Turkish pre-service science teachers' instructional technology-related self-efficacy perceptions and their instructional technology-related anxiety levels. When the bivariate and partial correlations between the instructional technology background available to Turkish pre-service science teachers and their instructional technology-related anxiety levels were analyzed, a positive correlation with average significance $(r=.44)$ was found between technological background and instructional technology-related anxiety; however, when other variables were controlled, the correlation between both variables was calculated to be $(\mathrm{r}=.31)$. Of the instructional technology-related attitude sub dimensions, the correlation between attitude toward having students use instructional technologies in the future and instructional technology-related anxiety was found to be positive at low level $(\mathrm{r}=.18)$. Further, a positive low-level $((\mathrm{r}=.20)$ correlation was found between attitude toward future classroom use of instructional technologies and instructional technology-related anxiety levels. In a similar vein, a low-level ( $\mathrm{r}=.01$ ) positive correlation was identified between the attitude toward contribution of instructional technologies to learning science and instructional technology-related anxiety. Technology experience, frequency of technology use, availability of access, instructional technology-related self-efficacy perception, instructional technology-related attitude variables yield a moderately significant correlation with Turkish pre-service science teachers' instructional technology-related anxiety scores $\left(R=.54, R^{2}=.29, p<.01\right)$. These eight variables together explain $29 \%$ of the total variance in the instructional technology-related anxiety level. According to the standardized regression coefficients $(\beta)$, predictor variables' order of relative significance regarding instructional technology-related anxiety is: technological background, technology experience, attitude toward having students use instructional technologies in the future, availability of access to technology, attitude toward future classroom use of instructional technologies, instructional technology-related self-efficacy perception, frequency of technology use, and attitude toward the contribution of instructional technologies to learning science. The t-test results regarding regression coefficients' significance reveal that, technology experience, technological background and attitude toward having students use instructional technologies in the future variables are significant predictors of instructional technology-related anxiety levels. 
As for the Swiss pre-service teachers, the regression analysis results regarding the predictivity of instructional technology-related anxiety according to the variables of technology experience, frequency of technology use, availability of access, instructional technology-related self-efficacy perception, instructional technology-related background, attitude toward having students use instructional technologies in the future, attitude toward future classroom use of instructional technologies, and attitude toward the contribution of instructional technologies to learning science are presented in Table 2.

Table 2. Multiple Regression Analysis Results Regarding the Prediction of Swiss Pre-service Science Teachers' Anxiety Towards Educational Technology

\begin{tabular}{|c|c|c|c|c|c|c|c|c|c|}
\hline $\begin{array}{l}\text { Dependent } \\
\text { Variable }\end{array}$ & & Predictors & B & $\begin{array}{l}\text { Std. } \\
\text { Error }\end{array}$ & $\beta$ & $\mathrm{t}$ & $\mathrm{p}$ & $\begin{array}{l}\text { Zero } \\
\text { order }\end{array}$ & Partial \\
\hline & & Constant & .973 & .509 & & 1.913 & .057 & & \\
\hline & & Technology experience & .121 & .056 & .160 & 2.169 & .031 & .285 & .160 \\
\hline Anxiety & Towards & Technology usage frequency & .054 & .033 & .133 & 1.628 & .105 & .347 & .121 \\
\hline Educational & & Availability of technology access & .006 & .043 & .010 & .128 & .898 & .249 & .010 \\
\hline \multirow[t]{5}{*}{ Technology } & & $\begin{array}{l}\text { Self-Efficacy towards educational } \\
\text { technology }\end{array}$ & .170 & .085 & .123 & 1.993 & .048 & .115 & .147 \\
\hline & & Technology background & .190 & .069 & .180 & 2.767 & .006 & .293 & .203 \\
\hline & & $\begin{array}{l}\text { Intention to provide opportunities for } \\
\text { their students to use technology in the } \\
\text { classroom }\end{array}$ & -.050 & .052 & -.078 & -.973 & .332 & -.067 & -.073 \\
\hline & & $\begin{array}{l}\text { Intention to use educational } \\
\text { technology in their teaching }\end{array}$ & .198 & .065 & .242 & 3.051 & .003 & .215 & .222 \\
\hline & & $\begin{array}{l}\text { The value of educational technology } \\
\text { for learning science. } \\
R=.577 \quad \mathrm{R}^{2}=.333 \\
\mathrm{~F}=11.188 \quad \mathrm{p}=.000\end{array}$ & -.222 & .047 & -.315 & -4.681 & .000 & -.366 & -.330 \\
\hline
\end{tabular}

The analysis of the bivariate and partial correlations between the predictor variables and dependent variable indicated that there was a low-level positive correlation $(\mathrm{r}=.28)$ between instructional technology-related anxiety level and technology experience, but when other variables were controlled, the correlation between the two variables was calculated as $r=.16$. Similarly, the correlation between frequency of technology use and instructional technology-related anxiety level is positive and low $(\mathrm{r}=.35)$. However, when other variables were controlled, this correlation was found to be $\mathrm{r}=.12$. A positive and low-level bivariate correlation $(\mathrm{r}=-.25)$ was calculated between Swiss science pre-service teachers' availability of technology access scores and their instructional technology-related anxiety levels. When the bivariate correlation between Swiss pre-service science teachers' instructional technology-related self-efficacy perceptions and their instructional technology-related anxiety levels was analyzed, a low-level positive correlation $(\mathrm{r}=.11)$ was found. On the other hand, when the bivariate and partial correlations between Swiss pre-service science teachers' instructional technology-related backgrounds and instructional technology-related anxieties were analyzed, a positive correlation with low-level significance $(r=.29)$ was found, however, when other variables were controlled, the correlation between the two variables was calculated as $r=.20$. On the other hand, the correlation between attitude toward having students use instructional technologies in the future and instructional technology-related anxiety was found to be negative and low $(\mathrm{r}=-.07)$. A positive low level $(\mathrm{r}=.21)$ correlation was found between attitude toward the future classroom use of instructional technologies and instructional technology-related anxiety. Also, a negative and low level $(\mathrm{r}=-.36)$ correlation was identified between attitude toward the contribution of instructional technologies to learning science and instructional technology-related anxiety. The variables of technology experience, frequency of technology use, availability of access, instructional technology-related self-efficacy and instructional technology-related attitude yield a moderately significant correlation with pre-service science teachers' instructional technology-related anxiety scores $\left(\mathrm{R}=.58, \mathrm{R}^{2}=.33, \mathrm{p}<.01\right)$. These aforementioned eight variables together explain $33 \%$ of the total variance in instructional technology-related anxiety.

According to the standardized regression coefficients $(\beta)$, predictor variables' relative order of significance regarding instructional technology-related anxiety is as follows: attitude toward the contribution of instructional technologies to learning science, attitude toward using instructional technologies in the future, instructional technology-related background, technology experience, frequency of technology use, instructional technology-related self-efficacy perception, attitude toward having students use instructional technologies in the future and availability of technology access. The analysis of the t-test results regarding the significance of regression coefficients reveal that, the variables of technology experience, instructional technology-related self-efficacy perception, instructional technology-related technological background, attitude toward the future classroom use of instructional technologies, and attitude toward the contribution of instructional technologies to learning science are significant predictors of instructional technology-related anxiety. 


\section{Discussion}

It was also found that as the Turkish and Swiss pre-service science teachers' technology experiences increase, so do their instructional technology-related anxiety levels. Some studies in the literature support the findings of the present study (Bozionelus, 2004, Fagan, Neill \& Wooldridge, 2004, Gardner, Discenza \& Dukes, 1993). However, Mahar, Henderson and Deane (1997) found a positively significant correlation between computer anxiety and computer experience. This can be said to stem from the constantly changing and advancing nature of technology. According to Chua, Chen and Wong (1999) technology activities temporarily reduce the computer-related anxiety level. Safford and Worthington (1999) state that as the skill level increases so does anxiety. Brosnan and Lee (1998) analyzed the relationship between computer anxiety and computer attitude of British and Chinese students. They found that the British participants had significantly higher computer experience than the Chinese. Furthermore, Chinese participants were found to have lower computer anxiety than the British participants. In their study focusing on computer-related anxiety levels of university students from different cultural backgrounds, Rosen and Weil (1995) found that Israel and Singapore were the countries where university students had low computer experience and low technology-related anxieties, the United States and Australia had students with high computer experiences and low technology-related anxieties, Japan had students with high computer experiences and high technology-related anxieties, while Saudi Arabia, Thailand, Kenya, Egypt, Greece and Italy had the students with low computer-related experiences and high technology-related anxieties. According to the results of the present study, as Turkish pre-service science teachers' frequency of technology use rises, their instructional technology-related anxiety level drops. However, as Swiss pre-service science teachers' frequency of technology use increases, their instructional technology-related anxiety levels do as well. While Brosnan and Lee's (1998) intercultural study found a negative relationship between British students' computer using frequency and their computer anxiety levels, it found a positive relationship between Chinese students' computer using frequency and their computer anxiety levels. Namlu and Ceyhan (2002) also concluded that a rise in computer using frequency lowers computer-related anxiety. Wilfong (2006) found a strong negative correlation between university students' computer anxiety and frequency of computer use. Bozionelos (2004) found a strong inverse correlation between computer anxiety and frequency of computer use. Our results show that, as Turkish pre-service science teachers' technology access increases, their instructional technology-related anxiety level drops. However, Swiss pre-service science teachers' availability of technology access parallels their instructional technology-related anxiety levels. Some studies in the literature report that students who have their own personal computers have low computer anxiety (Korobili, Togia \& Malliari, 2010, Arıkan, 2002, Colley et al., 1994). Tekinarslan (2008) concluded that German students had significantly lower computer anxiety than Turkish students and suggested that this was due to the fact that every German student had their own personal computer. Similarly, Ersoy and Kabakçı (2010) found that pre-service teachers' computer anxiety levels differ significantly depending on computer ownership, favoring computer owners. According to the results of the present study, for Turkish pre-service science teachers, higher perceptions of instructional technology-related self-efficacy means lower instructional technology-related anxiety levels. However, as Swiss pre-service science teachers' instructional technology-related self-efficacy perceptions increase, so do their instructional technology-related anxiety levels. While the relevant literature has some studies that report a negative correlation between technology anxiety and perception of technological self-efficacy (Pamuk \& Peker, 2009), some other studies report a positive correlation between these two variables (Saade \& Kira, 2009). An inverse relationship between German students' computer self-efficacy perceptions and their computer anxiety levels was also cited in the literature (Beckers \& Schmind, 2001). Wilfong (2006) suggested that so as to reduce users' anxiety levels, computer self-efficacy perceptions need to improve. However, Sam, Othman and Nordin (2005) point to the positive correlation between computer anxiety and computer self-efficacy perception. Tuncer (2012) identified a positive correlation between computer anxiety and computer self-efficacy perception as well. Li and Kirkup (2007) found that British students enjoy using computers more than Chinese students, but, Chinese students have less self-confidence than the British students in advanced computer skills. Another finding from the current study is that the richer Turkish and Swiss pre-service science teachers' instructional technology-related backgrounds are, the higher their instructional technology-related anxiety levels become. Also, there is a parallel rise in instructional technology-related anxiety levels as Turkish pre-service science teachers' attitude toward having students use instructional technologies in the future gets more positive. However, the more positive Swiss pre-service science teachers' attitude toward having students use instructional technologies in the future are, the lower their instructional technology-related anxiety levels are. The more positive Turkish and Swiss pre-service science teachers' attitude toward future classroom use of instructional technologies are, the higher their instructional technology-related anxiety levels. The more positive Turkish pre-service science teachers' attitude toward the contribution of instructional technologies to learning, the higher their instructional technology-related anxiety levels become, while the more positive Swiss pre-service science teachers' attitude is toward the contribution of instructional technologies to learning, the lower are their instructional technology-related anxiety levels. In their study where they analyzed the relationship between computer anxiety and computer attitude from an 
intercultural perspective, Brosnan and Lee (1998) found a significantly inverted correlation between British students' computer-related anxiety levels and their computer attitudes. However, a positive correlation was found between Chinese students' computer anxiety levels and their computer attitudes. Agbatogun (2010) found a positive correlation between Nigerian teachers' attitude toward instructional technology and their computer anxieties. Çataklı (2007) found that there was a negatively significant relationship between high school students' attitude and anxiety levels. Aiming to find out the computer anxiety levels and computer-related attitudes of students studying at Thessaloniki University Instructional Technologies Institute and Information Systems department, Korobili, Togia and Malliari (2010) found a strong negative relationship between computer anxiety and computer attitude. This present study found that Turkish pre-service science teachers' technology experiences, technological backgrounds, and attitudes toward having their students use instructional technologies in the future are significant predictors of their instructional technology-related anxiety levels. Swiss pre-service science teachers' technology experiences, instructional technology-related self-efficacy perceptions, instructional technology-related technological backgrounds, attitude toward the future classroom use of instructional technologies, and attitude toward the contribution of instructional technologies to learning science are significant predictors of instructional technology-related anxiety. The variables of technology experience, frequency of technology use, availability of access, instructional technology-related self-efficacy, and the instructional technology-related background, intention of having students use instructional technologies in the future, intention of future classroom use of them and contribution of instructional technologies to science learning as the instructional technology-related attitude sub dimensions together yield a moderately significant correlation with Turkish and Swiss pre-service science teachers' instructional technology-related anxiety scores. Furthermore, all together these eight variables explain $29 \%$ of the total variance in the Turkish pre-service science teachers' instructional technology-related anxiety level, and explain 33\% of the total variance in the Swiss pre-service science teachers' instructional technology-related anxiety level. Many studies in the literature underline that individuals' technology-related anxiety is affected by cultural differences, attitudes toward technology and self-efficacy perceptions (Ayersman \& Reed, 1995; Ertmer et al., 1994; Pamuk \& Peker, 2009, Agbatogun, 2010). Jawahar and Elango (2001) state that high anxiety about using technology leads to negative attitudes. Technology-related negative and positive attitudes have a crucial role in shaping technology anxiety (Blignaut, Mc Donald \& Tolmie, 2002). Instructional technology-related positive attitudes, high instructional technology-related self-efficacy perceptions and low anxiety levels are important facilitative factors in learning instructional technology skills in the process of integrating instructional technologies into higher education (Sam, Othman \& Nordin, 2005). Sproull, Zubrow and Kiesler (1986) found that some university students experience loss of control and get frustrated in the face of technology. Similarly, DeLoughry (1993) found that a third of the 14 million university students in the USA suffer from 'techno-phobia'. It is important for teacher candidates to view themselves as self-efficacious to overcome their instructional technology-related anxieties because pre-service teachers' instructional technology-related anxieties negatively affect their technology use and performance (Webster and Martocchio 1992).

\section{Conclusion and Suggestions}

This current study reveals that as Turkish and Swiss pre-service science teachers' technology experiences increase, so do their instructional technology-related anxiety levels. The more frequent Turkish pre-service science teachers' technology use is, the lower is their level of instructional technology-related anxiety. On the other hand, it was also found that higher rates of Swiss pre-service science teachers' frequency of technology use correspond to higher instructional technology-related anxiety levels. As Turkish pre-service science teachers' access to technology improves, their instructional technology-related anxiety drops. However, as the Swiss pre-service science teachers' access to technology gets better, their instructional technology-related anxiety levels also go up. The more positive Turkish pre-service science teachers' instructional technology-related self-efficacy perceptions are, the lower are their instructional technology-related anxiety levels. On the other hand, the higher Swiss pre-service science teachers' instructional technology-related self-efficacy perceptions are, the higher their instructional technology-related anxiety levels. Another finding from the current study is that Turkish and Swiss pre-service science teachers with richer instructional technology backgrounds have lower instructional technology-related anxiety levels. The more positive Turkish pre-service science teachers' attitude toward having students use instructional technologies in the future is, the higher their instructional technology-related anxiety levels are. However, the more positive Swiss pre-service science teachers' attitude toward having students use instructional technologies in the future is, the lower their instructional technology-related anxiety levels drop. Furthermore, the more positive Turkish and Swiss pre-service science teachers' attitude toward the future classroom use of instructional technologies, the higher their instructional technology-related anxiety levels become. The more positive Turkish pre-service science teachers' attitude toward the contribution of instructional technologies to learning science, the higher their instructional technology-related anxiety levels become, whereas the more positive Swiss pre-service science teachers' attitude toward the contribution of instructional technologies to learning science is, the lower their instructional technology-related anxiety levels become. 


\section{References}

Agbatogun, A. O. (2010). Self-concept, computer anxiety, gender and attitude towards interactive computer technologies: a predictive study among Nigerian teachers. International Journal of Education and Development Using Information and Communication Technology, 6(2), 2-14.

Akkoyunlu, B. (2002). Educational technology in Turkey: Past, present and future. Education Media International, 39(2), 165-173. http://dx.doi.org/10.1080/09523980210155352

Altun, T. (2002). Factors influencing teachers' change in classroom practice due to introduction of information and communications technology (ICT) in Turkey. Ed.D. Thesis, School of Education, University of Nottingham, United Kingdom.

Arıkan, D. (2002). Sinıf öğretmeni adaylarının bilgisayara yönelik tutumları, bilgisayar kaygı düzeyleri ve bilgisayar dersine ilişkin değerlendirmeleri, Unpublished master thesis, Dokuz Eylül Üniversitesi Eğitim Bilimleri Enstitüsü, Izmir.

Aşkar, P., \& Koçak, U. Y. (2003). Bilgisayarların benimsenme hızına ilişkin boylamsal bir çalışma: üç okulun karşılaştırılması. Hacettepe Üniversitesi- Eğitim Fakültesi Dergisi, 24, 15-25.

Aşkar, P., \& Umay, A. (2001). İlköğretim matematik öğretmenliği öğrencilerinin bilgisayarla ilgili özyeterlik algısı. Hacettepe Üniversitesi Ĕ̈itim Fakültesi Dergisi, 21, 1-8.

Ayersman, D. J., \& Reed, W. M. (1995). Effect of learning styles programming, and gen-der on computer anxiety. Journal of Research on Computing in Education, 28(2), 148-161. http://dx.doi.org/10.1080/08886504.1995.10782157

Beak, Y., Jung, J., \& Kim, B. (2008). What makes teachers use technology in the classroom? Exploring the factors affecting facilitation of technology with a Korean sample. Computer \& Education, 50, 224-234. http://dx.doi.org/10.1016/j.compedu.2006.05.002

Beckers, J. J., \& Schmidt, H. G. (2001). The structure of computer anxiety: A six-factor model. Computers in Human Behavior, 17, 35-49. http://dx.doi.org/10.1016/S0747-5632(00)00036-4

Blignaut, P. J., Mc Donald, T., \& Tolmie, J. (2002). The Influence of Experience, Culture and Spatial Visualization Ability on Users' Attitudes and Anxiety towards Computer Use. Edt; E. J. Szewczak \& C. R. Snodgrass, Human Factors in Information Systems, 269-280, Idea Group Publishing, Hershey, PA, USA. http://dx.doi.org/10.4018/978-1-931777-10-0.ch019

Bond, M. H. (1986). Lifting One of the Last Bamboo Curtains: Review of the Psychology of the Chinese People. Hong Kong: Oxford University Press.

Bozionelos, N. (2004). Sd computer experience in their relationship, International Journal of Human-Computer Studies, 61, 725-746. http://dx.doi.org/10.1016/j.ijhcs.2004.07.001

Brosnan, M. J., \& Lee, W. (1998). A cross-cultural comparison of gender differences in computer attitudes and anxieties: The United Kingdom and Hong Kong. Computers in Human Behavior, 14, 559-577. http://dx.doi.org/10.1016/S0747-5632(98)00024-7

Buzzard, C., Crittenden, V., Crittenden, W., \& McCarty, P. (2011). The use of digital technologies in the classroom: A teaching and learning perspective. Journal of Marketing Education, 33(2) 131-139. http://dx.doi.org/10.1177/0273475311410845

Campoy, R. (1992). The role of technology in the school reform movement. Educational Technology, 32(8), 17-22.

Çataklı, Ö. Y. (2007). Bilgisayar teknik lisesi ögrencilerinin bilgisayar tutumları ile bilgisayar kaygılarının incelenmesi: Anadolu bilgisayar teknik lisesi uygulamast, Unpublished Master Thesis. University of YediTepe, İstanbul.

Ceyhan, E. (2006). Computer anxiety of teacher trainees in the framework of personality variables. Computers in Human Behavior, 22, 207-220. http://dx.doi.org/10.1016/j.chb.2004.07.002

Chau, P. Y. K. (2001). Influence of computer attitude and self-efficacy on IT usage behavior. Journal of End User Computing, 13(1), 26-33. http://dx.doi.org/10.4018/joeuc.2001010103

Chua, S. L., Chen, D. T., \& Wong, F. L. (1999). Computer anxiety and its correlates: A meta-analysis. Computers in Human Behavior, 15, 609-623. http://dx.doi.org/10.1016/S0747-5632(99)00039-4

Coffin, R., \& Mackintyre, P. (2000). Cognitive, motivation, and affective processes associated with computer related performance: A path analysis. Computers in Human Behavior, 16(2), 199-222. http://dx.doi.org/10.1016/S0747-5632(99)00054-0 
Colley, A., Gale, M., \& Harris, T. (1994). Effect of gender role identity and experience on computer attitude components. Journal of Educational Computing Research, 10(2), 129-137. http://dx.doi.org/10.2190/8NA7-DAEY-GM8P-EUN5

Compeau. D. R., \& Higging, S. C. A. (1995). Computer self-efficacy: Development of a measure and initial test. MIS Quarterly, 19(2), 189-211. http://dx.doi.org/10.2307/249688

Deloughry, T. J. (1993). Two researchers say 'Technophobia' may afflict millions of students. Chronicle of Higher Education, 39(34), A25-26.

Demirarslan, Y., \& Usluel, K. Y. (2005). Bilgi ve iletişim teknolojilerinin öğrenme öğretme sürecine entegrasyonunda öğretmenlerin durumu. The Turkish Online Journal of Educational Technology, 4(3), 109-113.

Doyle, E., Stamouli, I., \& Huggard, M. (2005). Computer anxiety, self-efficacy, computer experience: An investigation throughout a computer science degree. 35th Annual SEE/IEEE Frontiers in Education Conference, 19-22 Sept. 2005, Indianapolis, Indiana. http://dx.doi.org/10.1109/FIE.2005.1612246

Durndell, A., Haag, Z., \& Laithwaite, H. (2000). Computer self-efficacy and gender: A cross cultural study of Scotland and Romania. Personality and Individual Differences, 28, 1037-1044. http://dx.doi.org/10.1016/S0191-8869(99)00155-5

Efe, R. (2011). Science student teachers and educational technology: experience, intentions and value. Educational Technology \& Society, 14(1), 228-240.

Ersoy, M., \& Kabakçı, I. (2010). İlköğretim Matematik Öğretmen Adaylarının Bilgisayar Kaygı Düzeylerinin Çeşitli Değişkenler Açısından İncelenmesi. Eğitim Teknolojileri Araştırmaları Dergisi, 1(4).

Ertmer, P. A. (2005). Teacher pedagogical beliefs: The final frontier in our quest for technology integration. Education Tech. Research Dev., 53(4), 25-39. http://dx.doi.org/10.1007/BF02504683

Ertmer, P. A., Evenbeck, E., Cennamo, K., \& Lehman, J. (1994). Enhancing self efficacy for computer technologies through the use of positive classroom experiences. ETR\&D, 42(3), 45-62. http://dx.doi.org/10.1007/BF02298094

Fagan, M. H., Neill, S., \& Wooldridge, B. R. (2004). An empirical investigation into the relationship between computer self-efficacy, anxiety, experience, support and usage. The Journal of Computer Information Systems, 44(2), 95-104.

Gardner, D. G., Discenza, R., \& Dukes, R. C. (1993). The measurement of computer attitudes, an empirical comparisons of available scales. Journal of Educational Computing Research, 9(4), 487-507. http://dx.doi.org/10.2190/DXLM-5J80-FNKH-PP2L

Garris, R., Ahlers, R., \& Driskell, J. E. (2002). Games, motivation, and learning: A research and practice model. Simulation \& Gaming, 33(4), 441-467. http://dx.doi.org/10.1177/1046878102238607

Halis, İ. (2002). Öğretim Teknolojileri ve Materyal Geliştirme, Nobel Yayınları, Sayfa 154, Ankara.

Harris, S. R., Kemmerling, R. L., \& North, M. M. (2002). Brief virtual reality therapy for public speaking anxiety. Cyberpsychology and Behavior, 5(6), 543-550. http://dx.doi.org/10.1089/109493102321018187

Hasan, B. (2003). The influence of specific computer experiences on computer self-efficacy beliefs. Computers in Human Behavior 19,443-450. http://dx.doi.org/10.1016/S0747-5632(02)00079-1

Huang, H. M., \& Liaw, S. S. (2005). Exploring user's attitudes and intentions toward the web as a survey tool. Computers in Human Behavior, 21(5), 729-743. http://dx.doi.org/10.1016/j.chb.2004.02.020

Jawahar, I. M., \& Elango, B. (2001). The effects of attitudes, goal setting, and self efficacy on end user performance. Journal of End User Computing, 13(2), 40-45. http://dx.doi.org/10.4018/joeuc.2001040104

Kanfer, R., \& Heggestad, E. D. (1997). Motivational traits and skills: A person-centered approach to work motivation. Research in Organizational Behavior, 19, 1-56.

Karsten, R., \& Roth, R. (1998). The relationship of computer experience and computer self-efficacy to performance in introductory computer literacy courses. Journal of Research on Computing Education, 31(1), 14-24. http://dx.doi.org/10.1080/08886504.1998.10782238

Khine, M. S. (2001). Attitudes toward computers among teacher education students in Brunei Darussalam. International Journal of Instructional Media, 28(2), 147-153.

King, P. K. (2002). Educational technology professional development as transformative learning opportunities. Computers and Education, 39(3), 283-297. http://dx.doi.org/10.1016/S0360-1315(02)00073-8

Komis, V., Ergazakia, M., \& Zogzaa, V. (2007). Comparing computer-supported dynamic modelling and 'paper \& 
pencil' concept mapping technique in students' collaborative activity. Computers \& Education, 49(4), 991-1017. http://dx.doi.org/10.1016/j.compedu.2005.12.007

Korobili, S., Togia, A., \& Malliari, A. (2010). Computer anxiety and attitudes among under-graduate students in Greece. Computers in Human Behavior, 26, 399-405. http://dx.doi.org/10.1016/j.chb.2009.11.011

Kozma, R. (2003). Technology, Innovation, And Educational Change: A Global Perspective. International Society for Technology in Education, p. 36. Eugene, OR.

Kumar, P., \& Kumar, A. (2003). Effects of web-based projects on pre-service and inservice teachers' attitudes towards computers and technology skills. Journal of Computing in Teacher Education, 19(3), 87-92.

Kutluca, T., \& Ekici, G. (2010). Investigation of prospective teachers' attitudes and self-efficacy perceptions related to computer-assisted instruction. Hacettepe University Journal of Education, 38, 177-188.

Li, N., \& Kirkup, G. (2007). Gender and cultural differences in Internet use: A study of China and the UK, Computers \& Education, 48, 301-317. http://dx.doi.org/10.1016/j.compedu.2005.01.007

Mahar, D., Henderson, R., \& Deane, F. (1997). The effects of computer anxiety, state anxiety, and computer experience on users' performance of computer based tasks, person. Indiuid. Dijjf., 22(5), 683-692.

Marcoulides, G. A. (1989). Measuring computer anxiety: The computer anxiety scale. Educational and Psychological Measurement, 49, 733-740. http://dx.doi.org/10.1177/001316448904900328

Marcoulides, G. A., \& Wang, X. (1990). A cross-cultural comparison of computer anxiety in college students. Journal of Educational Computing Research, 6, 251-263. http://dx.doi.org/10.2190/CVYH-M8F9-9WDV-38JG

McCannon, M., \& Crews, T. B. (2000). Assessing the technology needs of elementary school teachers. Journal of Technology and Teacher Education, 8(2), 111-121.

Mcllroy, D., Bunting, B., Tierney, K., \& Gordon, M. (2001). The relation of gender and background experience

Middlehurst, R. (1999). New realities for leadership and governance in higher education. Tertiary Education and Management, 5, 307-329. http://dx.doi.org/10.1080/13583883.1999.9966999

Milli Eğitim Bakanlığı (MEB), (2004). İlköğretim fen ve teknoloji dersi (4-5.sınıflar) öğretim programı, Ankara: Devlet Kitapları Müdürlüğü Basımevi.

Mumtaz, S. (2000). Factor affecting teachers' use of information and communications technology: a review of the literature. Journal of Information Technology for Teacher Education, 9(3), 319-342. http://dx.doi.org/10.1080/14759390000200096

Namlu, A., \& Ceyhan, E. (2002). Computer anxiety: A study on university students. Eskisehir: Anadolu University Publishing.

Pamuk, Ş., \& Peker, D. (2009). Turkish pre-service science and mathematics teachers' computer related self-efficacies, attitudes, and the relationship between these variables. Computers and Education, 53, 454-461. http://dx.doi.org/10.1016/j.compedu.2009.03.004

Pelgrum, W. J. (2001). Obstacles to the integration of ICT in Education: results from a worldwide educational assessment. Computers \& Education, 37(2) 163-178. http://dx.doi.org/10.1016/S0360-1315(01)00045-8

Rosen, L. D., \& Weil, M. M. (1995). Computer anxiety: A cross-cultural comparison of university students in ten countries. Computer in Human Behavior, 11(1), 45-64. http://dx.doi.org/10.1016/0747-5632(94)00021-9

Saade, R. G., \& Kira, D. (2009). Computer anxiety in e-learning: The effect of computer self-efficacy. Journal of Information Technology Education.

Safford, S. M., \& Worthington, J. E. (1999). Computer anxiety in individuals with serious mental illness. Computers in Human Behavior, 15(6), 735-745. http://dx.doi.org/10.1016/S0747-5632(99)00043-6

Salanova, M., Grau, R. M., Cifre, E., \& Llorens, S. (2000). Computer training, frequency of usage and burnout: the mode-rating role of computer self-efficacy. Computers in Human Behavior, 16, 575-590. http://dx.doi.org/10.1016/S0747-5632(00)00028-5

Sam, H. K., Othman, A. E. A., \& Nordin, Z. S. (2005). Computer self-efficacy, computer anxiety, and attitudes toward the internet: a study among under-graduates in Unimas. Educational Technology \& Society, 8(4), 205-219.

Sarıtaş, T., \& Üner, N. (2013). Eğitimdeki Yenilikçi Teknolojiler: Bulut Teknolojisi, Eğitim ve Öğretim Araştır-maları Dergisi, 2(3), 192-201.

Seferoğlu, S. (2005). A study on primary school teachers' perceived computer self-efficacy. Educational Research, 19, 
89-101.

Seferoğlu, S., Akbıyık, C., \& Bulut, M. (2008). İlköğretim öğretmenlerinin ve öğretmen adaylarının bilgisayar-ların öğrenme/öğretme sürecinde kullanımı ile ilgili görüşleri, Hacettepe Üniversitesi Eğitim Fakültesi Dergisi. 35, 273-283.

Sensales, G., \& Greenfield, P. M. (1995). Attitudes toward computers, science, and technology: A cross-cultural comparison between students in Rome and Los Angeles. Journal of cross-cultural Psychology, 26, $229-242$. http://dx.doi.org/10.1177/0022022195263001

Smith, B., Caputi, P., \& Rawstorne, P. (2000). Differentiating computer experience and attitudes toward computers: An emprical investigation. Computers in Human Behavior, 16, 59-81. http://dx.doi.org/10.1016/S0747-5632(99)00052-7

Spielberger, C. D. (1983). Manual for the State-Trait Anxiety Inventory. Palo Alto, CA: Consulting Psychologists Press.

Sproull, L., Zubrow, D., \& Kiesler, S. (1986). Cultural socialization to computing in college. Computers in Human Behavior, 2, 257-275. http://dx.doi.org/10.1016/0747-5632(86)90007-5

Tekinarslan, E. (2008). Computer anxiety: A cross-cultural comparative study of Dutch and Turkish university students. Computers in Human Behavior, 24, 1572-1584. http://dx.doi.org/10.1016/j.chb.2007.05.011

to self-reported compu-ting anxiety and cognitions. Computers in Human Behavior, 17(1), 21-33.

Tuncer, M. (2012). Investigation of effects of computer anxiety and internet attitudes on computer self-efficacy. International Journal of Social Science, 5(4), 205-222. http://dx.doi.org/10.9761/jasss_156

Ursavaş, Ö. F., Mcllroy, D., \& Şahin, S. (2011). Computer phobia in higher education: A comparative analysis of United Kingdom and Turkish university students. Gaziantep Üniversitesi Sosyal Bilimler Dergisi, 10(4), 1271-1290.

Usluel, Y., \& Seferoğlu, S. S. (2003). Eğitim fakültelerindeki öğretim elemanlarının bilgisayar kullanımı ve öz-yeterlik algıları. Bilişim Teknolojileri Işığında Eğitim Konferansı ve Sergisi (BTIE-2003), 21-23 Mayıs, ODTÜ Kültür ve Kongre Merkezi, Ankara.

Wang, Q., \& Leichtman, M. D. (2000). Same beginnings, different stories: A comparison of American and Chinese children's narratives. Child Development, 71, 1329-1346. http://dx.doi.org/10.1111/1467-8624.00231

Webster, J., \& Martocchio, J. J. (1992). Micro-computer playfulness: Development of a measure with workplace implications. MIS Quarterly, 16(2), 201-226. http://dx.doi.org/10.2307/249576

Wilfong, J. D. (2006). Computer anxiety and anger: The 1mpact of computer use, computer experience, and self-efficacy beliefs. Computers in Human Behavior, 22, 1001-1011. http://dx.doi.org/10.1016/j.chb.2004.03.020

Williams, H. S., \& Kingham, M. (2003). Infusion of technology into the curriculum. Journal of Instructional Psychology, 30(3), 178-184.

Yıldırım, S., Koçak, S., \& Kirazc1, S. (2001). Computers are ready but how about teachers: An assessment of Turkish basic education teachers' inservice training needs. Paper presented at the 12th Annual International Conference of Society for Information Technology \& Teacher Education. Association for the Advancement of Computing in Education (AACE), Orlando, Florida, April 2001.

Zhao, Y., Tan, H. S., \& Mishra, P. (2001). Teaching and learning: Whose computer is it? Journal of Adolescent \& Adult Literacy, 44(4), 348-354. 